\title{
HUBUNGAN PENGETAHUAN TENTANG SASTRA DAN MINAT MEMBACA KARYA SASTRA DENGAN KEMAMPUAN MENGAPRESIASI KARYA SASTRA (STUDI KORELASI PADA MAHASISWA FKIP (LUAR JURUSAN PBS)) UNIVERSITAS HAMZANWADI
}

\author{
Eva Nurmayani ${ }^{1}$, Hilmiyatun ${ }^{2}$ \\ rama_restu@yahoo.com, hilmiya_miya@yahoo.co.id
}
Prodi Pendidikan Bahasa dan Sastra Indonesia, Fakultas Keguruan dan Ilmu Pendidikan
Universitas Hamzanwadi Selong, Indonesia

\begin{abstract}
Abstrak
Penelitian ini bertujuan untuk mengetahui: (1) hubungan antara pengetahuan tentang sastra dan kemampuan mengapresiasi karya sastra; (2) hubungan antara minat membaca karya sastra dan kemampuan mengapresiasi karya sastra; dan (3) hubungan antara pengetahuan tentang sastra dan minat membaca karya sastra secara bersama-sama dengan kemampuan mengapresiasi karya sastra. Penelitian ini dilaksanakan di Universitas Hamzanwadi Selong Kabupaten Lombok Timur Nusa Tenggara Barat. Metode Penelitian yang digunakan adalah metode survei korelasi. Instrumen untuk mengumpulkan data adalah tes kemampuan mengapresiasi karya sastra, angket pengetahuan tentang sastra, dan angket minat membaca karya sastra. Teknik analisis data yang digunakan adalah teknik analisis regresi dan korelasi (sederhana dan ganda). Berdasarkan hasil penelitian dapat disimpulkan bahwa, baik secara sendiri-sendiri maupun bersama-sama, pengetahuan tentang sastra dan minat membaca karya sastra memberikan kontribusi yang berarti pada kemampuan mengapresiasi karya sastra
\end{abstract}

Kata kunci: karya sastra, minat membaca, pengetahuan tentang sastra

\begin{abstract}
The objectives of this study are to know: (1) the relationbetween the knowledge about literature and the ability to appreciate literature works; (2) the relation between reading interest on literature works and the ability to appreciate literature works; and (3) the relation between the knowledge about literature and reading intereston literature works with the ability to appreciate literature works.This study conducted in University of Hamzanwadi, Selong, East Lombok, West Nusa Tenggara. The method was correlation survey. The instruments were the test to know the ability to appreciate literature works, questionnaire about the knowledge of literature, and questionnaire about reading interest on literature works. The data analysis used regresion and correlation technics (simple and multiple). The conclusion of the study are the knowledge about literature and reading interest about literature works have meaningful contribution on the ability to aprreciate literature works.
\end{abstract}

Keyword : literature works, reading interest, knowledge about literature

\section{PENDAHULUAN}

Perkembangan karya sastra di era digital ini sangatlah pesat. Karya sastra disuguhkan dengan berbagai cara agar mudah memperolehnya. Kehadirannya berseliweran dimanamana tentunya bertujuan agar sampai kepada

pencintanya. Ketersediaannya sebagai sarana untuk mempermudah dan menunjang kebutuhan manusia tentu berdampak positif bagi konsumennya. Pemanfaatan seperti inilah menjadi peluang bagi pencinta sastra dengan mudah mengakses karya sastra, bertemu dengan komunitas pencinta sastra atau sekedar berdialog ringan yang berkaitan dengan karya sastra.

Tidak berhenti sampai disana, kreativitas sastrawan lokal maupun nasional selalu muncul dalam eveneven tertentu untuk memperkenalkan karya sastra. Hal semacam ini dilakukan untuk memikat daya tarik masyarakat atau pencinta sastra lainnya. Mereka senantiasa meluangkan waktu untuk 
mengapresiasi sastra sesuai dengan keahlian yang mereka miliki. Misalnya melakukan pementasan drama, pembacaan puisi atau menyediakan ruang dan waktu untuk berdiskusi berkaitan dengan karya sastra yang pernah dibaca. Hal ini dilakukan untuk menggerakkan apresiasi sastra bagi mereka yang belum mampu mengapresiasi sastra dengan baik.

Fenomena yang disebutkan di atas tidak dapat memberikan jaminan mutlak atas tercapainya kemampuan mengapresiasi sastra. Kemampuan mengapresiasi sastra yang baik tentunya dibarengi dengan langsung dengan menggeluti karya sastra itu sendiri. Sebab, ketika mengapresiasi sastra sesorang harus berhubungan langsung atau mengenal sastra secara langsung (Waluyo, 2011: 31). Tanpa mengenalnya terlebih dahulu tentu menjadi tidak mudah dalam mengapresiasinya. Dengan demikian, mengenal karya sastra merupakan bagian dari tahapan apresiasi. Apresiasi inilah yang memotivasi mahasiswa menuju ke tahapan apresiasi berikutnya.

Apabila dicermati dalam keseharian, tidak semua mahasiswa memiliki pengetahuan tentang sastra. Mereka menganggap karya sastra sebagai tumpukan buku yang berjilid-jilid kemudian berjejer rapi di perpustakaan (apabila berupa prosa puisi, dan naskah drama). Selain itu, mereka juga menganggap karya sastra hanya lakon orang-orang tidak waras dengan penuh kepurapuraan di atas panggung (apabila berupa drama). Selanjutnya, menjadi bahasa indah yang selalu mereka lontarkan pada kekasih hati mereka saat mengutarakan perasaannya (apabila berupa puisi). Alasan seperti ini membuktikan bahwa pengetahuan tentang karya sastra mahasiswa sangatlah dangkal. Dengan demikian, kemampuan mengapresiasi karya sastra sangatlah rendah. Apalagi jika mereka berada diluar jurusan pendidikan bahasa dan seni yang intensitasnya kurang bersentuhan langsung dengan karya sastra.

Kurangnya pengetahuan tentang sastra tentunya akan berdampak pada kurangnya minat membaca karya sastra. Mahasiswa lebih tertarik mengikuti perkembangan teknologi yang terus menggiurkan. Kondisi ini menjadikan mahasiswa lupa akan tugasnya sebagai mahasiswa yang harus dekat dengan buku juga membacanya. Kehadiran inovasi teknologi yang terus pesat menjadikan mereka menyampingkan hal-hal yang seharusnya mereka butuhkan dalam menempuh kuliahnya. Akibatnya kemampuan dalam mengapresiasi karya sastra mahasiswa cukup memprihatinkan, apalagi mereka yang berada diluar jurusan bahasa dan seni. Bagi mereka membaca karya sastra bukanlah prioritas utama melainkan sebagai pengisi waktu senggang jika tidak ada bacaan lain yang lebih menarik.

Berdasarkan uraian di atas, penelitian ini dibatasi pada: (a) apresiasi karya sastra dibatasi pada tiga genre sastra yakni berupa puisi, prosa (dalam bentuk cerpen maupun novel), dan drama (naskah drama); (b) apresiasi sastra berkaitan dengan mengenal, memahami dan menghayati karya sastra; (d) minat membaca karya sastra dibatasi pada minat membaca prosa, puisi, dan drama (naskah drama). Maka permalahan dalam penelian ini 
adalah: (1) adakah hubungan antara pengetahuan tentang sastra dengan kemampuan mengapresiasi karya sastra?; (2) adakah hubungan antara minat membaca karya sastra dengan kemampuan mengapresiasi karya sastra?; dan (3) adakah hubungan antara pengetahuan tentang sastra dan minat membaca karya sastra secara bersama-sama dengan kemampuan mengapresiasi karya sastra?

\section{KAJIAN TEORI}

\section{Kemampuan Mengapresiasi Karya Sastra}

Kemampuan pada hakikatnya merupakan kesanggupan seseorang dalam melakukan sesuatu. Selanjutnya kemampuan didefinisikan sebagai kesanggupan dalam melakukan suatu perbuatan (Chaplin, 2011:1). Sementara, Erich Jaensch (dalam Wellek dan Warren, 1989: 94) mengartikan kemampuan sebagai gejala menyatunya kemampuan berpikir dan kemampuan pengindraan. Oleh karena itu kesanggupan berpikir dan pengindaraan haruslah sejalan dan saling mendukung untuk mendapatkan harapan yang diinginkan.

Merujuk uraian di atas disimpulkan bahwa kemampuan merupakan perilaku, tanggapan, serta tindakan mahasiswa untuk menunjukkan aktivitas. Dalam kaitannya dengan penelitian ini yaitu "kemampuan mengapresiasi karya sastra" berarti tindakan, aktivitas serta kesanggupan yang ditunjukkan mahasiswa dalam mengapresiasi karya sastra.

Syah (2010: 122) menjelaskan apresiasi merupakan pertimbangan (judgment) atau nilai penting dari suatu objek. Selain itu, apresiasi diartikan sebagai upaya memahami karya sastra yang dibaca, termasuk mengerti maknanya secara intensional maupun aktual serta mengerti seluk-beluk struktur karya sastra Sayuti (2000: 3). Lebih lanjut Aminuddin (1995: 40) mendefinisikan apresiasi sastra ialah pemberian harga pada suatu karya sastra yang diperoleh dari pemahaman dan penghayatan.

Sesuai dengan uraian di atas, dapat disimpulkan bahwa kemampuan mengapresiasi karya sastra diartikan sebagai kesanggupan atau kemahiran yang dimiliki mahasiswa dalam mengenal, memahami, dan menghayati serta memberikan tanggapan penilaian terhadap karya sastra. Akan tetapi, apresiasi karya sastra pada kesempatan ini dibatasi pada kesanggupan atau kemahiran yang dimiliki mahasiswa dalam mengenal, memahami, dan menghayati karya sastra.

Kemampuan mengapresiasi karya sastra dibatasi pada: (1) mengenal; (2) memahami; dan (3) menghayati karya sastra. Selanjutnya, pengukuran kemampuan mengapresiasi karya sastra dilakukan menggunakan tes objektif berbentuk pilihan ganda (multiple choice). Indikator yang digunakan untuk mengukur apresiasi karya sastra yakni: (1) kemampuan mengenal karya sastra; kemampuan memahami karya sastra; dan (3) kemampuan menghayati karya sastra.

\section{Pengetahuan tentang Sastra}

Pengetahuan atau knowloge ialah usaha seseorang untuk tahu. Tahu diartikan sebagai usaha yang dapat dilakukan seseorang untuk 
mengerti dan pandai (Salam, 2003). Selanjutnya, pengetahuan diartikan sebagai usaha penginderaan seseorang terhadap suatu obyek melalui penginderaannya (Notoatmodjo, 2005:50). Selain itu, pengetahuan diperoleh sebagian besar dari mata dan telinga manusia (Notoatmodjo (2005). Dengan demikian pengetahuan diartikan sebagai usaha manusia untuk tahu dengan menggunakan indera yang dimilikinya. Apabila dikaitkan dengan pengetahuan tentang sastra dapat diartikan sebagai usaha manusia untuk tahu tentang sastra dengan menggunakan indera yang dimiliki.

Berikut beberapa komponen yang berimbas pada pengetahuan (Notoatmodjo (2007): Pertama, Pendidikan. Pendidikan diasumsikan sebagai ikhtiar seseorang yang dapat mempengaruhi proses belajarnya. Kedua, mass media/informasi. Masuknya informasi baru dapat mempengaruhi pengetahuan seseorang. Ketiga, tingkatan ekonomi seseorang dapat mempengaruhi tersedianya suatu fasilitas yang mampu mempengaruhi pengetahuan sesorang. Keempat, lingkungan. Lingkungan disini diartikan sebagai lingkungan tempat tinggal seseorang yang dapat mempengaruhi masuknya pengetahuan seseorang. Sebab, interaksi sosial yang terjadi di dalamnya dapat mempengaruhi pengetahuan seseorang.

Berikutnya, faktor kelima, yakni pengalaman. Pengalaman sangat berperan dalam mempengaruhi pengetahuan seseorang, baik pengalaman pribadi maupun pengalaman orang lain dapat mempengaruhi pengetahuan. Faktor terakhir, yakni usia. Usia berpengaruh pada ingatan dan cara berpikir. Usia (41-60 tahun) ialah usia kematangan berpikir. Di sini, seseorang tinggal mempertahankan prestasi yang dimilikinya Sebaliknya, usia (>60 tahun) seseorang tinggal menikmati hasil dari prestasinya. Dengan demikian, seseorang yang semakin tua akan semakin bijaksana. Sebab, pada usia tua seseorang sudah memiliki berbagai macam informasi yang dapat menambah pengetahuannya.

Pengukuran pengetahuan tentang sastra pada penelitian ini menggunakan non tes, menggunakan kuesioner (angket) yakni sejumlah pernyataan yang ditanggapi responden. Adapun aspek-aspek sebagai indikator untuk mengukur pengetahuan tentang sastra yakni mengacu pada pendapat Notoatmodjo (2007) seperti yang diuraikan sebelumnya.

\section{Minat Membaca Karya Sastra}

Minat adalah perasaan lebih suka dan keterikatan pada suatu hal atau aktivitas tanpa ada yang menyuruh (Djaali, 2012: 121). Lebih lanjut, minat diartikan sebagai ketertarikan seorang terhadap sesuatu (Djamarah, 2011: 166). Selanjutnya, minat didefinisikan sebagai sikap perhatian yang berlangsung secara terus-menerus terhadap objek yang disukai (Chaplin, 2011: 255). Dengan demikian, minat merupakan ketertarikan seseorang secara terusmenerus yang mendorongnya untuk melakukan suatu hal tanpa ada yang menyuruhnya.

Membaca adalah aktivitas fisik dan mental secara kompleks. Aktivitas fisik yakni membaca yang melibatkan intensitas penglihatan, 
sedangkan mental melibatkan impresi dan penafsiran (Abdurrahman, 2003: 200). Selain itu, membaca diartikan sebagai aktivitas memperoleh pesan yang disajikan oleh penulis melalui bahasa tulis (Tarigan, 2008: 7). Oleh karena itu, aktivitas membaca bisa dilakukan oleh siapa saja, dimana, dan kapan saja serta membaca objek bacaan apa saja. Tujuannya untuk memperoleh informasi dan memahami objek yang dibaca. Jadi, aktivitas membaca adalah aktivitas yang dilakukan seseorang untuk mendapatkan informasi dan makna terhadap objek bacaan yang disampaikan penulis melalui tulisannya.

Upaya menggiatkan minat membaca mahasiswa tentunya harus didukung oleh berbagai pihak diantaranya peranan orang tua, dosen, masyarakat, dan pemerintah. Dari keempat pihak tersebut orang tua dan dosenlah yang memiliki peranan yang cukup besar sebab kedua pihak ini memiliki kedekatan emosional yang paling dekat dengan mahasiswa. Orang tua haruslah membimbing anaknya untuk melakukan kegiatan membaca sejak dini di rumah, sedangkan dosen seyogyanya turut serta berpartisipasi aktif dalam menggiatkan minat membaca di kampus.

Berdasarkan paparan di atas peran orang tua dan dosen sangat mempengaruhi aktivitas membaca mahasiswa. Oleh karena itu, untuk memperoleh data minat membaca karya sastra diperlukan indikatorindikator sebagai petunjuk adanya minat membaca karya sastra yang hendak diungkap atau diukur. Dalam konteks penelitian ini digunakan alat evaluasi yang dipandang tepat, ajeg, dan sahih, yakni disajikan dalam bentuk kisi-kisi yang mencakup tiga aspek minat membaca karya sastra yaitu: (1) pemilihan jenis bacaan yang sesuai, (2) pengelolaan waktu membaca, dan (3) fasilitas penunjang buku bacaan.

Berpijak dari telaah minat dan membaca di atas apabila dikaitkan dengan karya sastra maka minat membaca karya sastra dapat diartikan sebagai ketertarikan siswa secara terus-menerus tanpa ada yang menyuruhnya dengan melakukan pemilihan jenis bacaan yang sesuai, pengelolaan waktu membaca, dan pemanfaatan fasilitas penunjang buku bacaan yang tersedia dalam membaca karya sastra.

\section{Hipotesis}

$\begin{array}{rr}\text { Berdasarkan } & \text { deskripsi } \\ \text { dimuka, teoretis, } & \text { hipotesis } \\ \text { menunjukkan : } & \text { (1) terdapat }\end{array}$ hubungan positif antara pengetahuan tentang sastra dengan kemampuan mengapresiasi karya sastra; (2) terdapat hubungan positif antara minat membaca karya sastra dengan kemampuan mengapresiasi karya sastra; dan (3) terdapat hubungan positif antara pengetahuan tentang sastra dan minat membaca karya sastra terhadap kemampuan mengapresiasi karya sastra.

\section{METODE PENELITIAN}

Penelitian ini dilaksanakan di Universitas Hamzanwadi. Subjek penelitian adalah mahasiswa FKIP Universitas Hamzanwadi tahun akademik 2017/2018. Penelitian ini metode survei. Metode survei cocok digunakan dalam penelitian korelasional. Metode survei dipilih karena penelitian ini merupakan studi korelasional yang berfungsi 
untuk mendeteksi variasi-variasi pada satu atau lebih berdasarkan pada koefisien korelasi (Suwarto dan Slamet, 2007:33).

Pada penelitian ini terdapat dua variabel bebas, pengetahuan tentang sastra disebut sebagai $\mathrm{X}_{1}$ dan minat membaca karya sastra disebut sebagai $\mathrm{X}_{2}, \quad$ variabel yakni kemampuan mengapresiasi karya sastra (Y). Berikut definisi operasion variabelnya: (1) kemampuan mengapresiasi karya sastra adalah kesanggupan (kemahiran) mahasiswa dalam mengenal, memahami, dan menghayati karya sastra. Indikator yang digunakan untuk mengukur kemampuan mengapresiasi karya sastra yaitu: (a) kemampuan mengenal karya sastra, kemampuan memahami karya sastra, dan (c) kemampuan menghayati karya sastra. (2) Pengetahuan tentang sastra adalah kemahiran yang dimiliki mahasiswa berkaitan dengan sastra. Indikator yang digunakan dalam hal ini yaitu beberapa hal yang mempengaruhi pengetahuan meliputi; (a) pendidikan; (b) mass media/informasi; (c) sosial budaya dan ekonomi; (d) lingkungan; (e) pengalaman; dan (f) Usia. Selanjutnya (3) Minat membaca karya sastra adalah ketertarikan mahasiswa secara terus menerus tanpa ada yang menyuruhnya dalam membaca karya sastra (berupa: prosa, puisi, dan drama). Indikator dalam menentukan minat membaca karya sastra dibatasi pada hal-hal berikut: (a) kemampuan memilih jenis bacaan yang sesuai; (b) kemampuan mengelola waktu membaca; dan (c) fasilitas penunjang buku bacaan.

Data

mengapresiasi dikumpulkan dengan teknik tes. Tes untuk mengukur kemampuan mengapresiasi karya sastra dan pengetahuan awal tentang sastra diukur dengan tes objektif (pilihan ganda). Selanjutnya, teknik non tes berupa pemberian kuesioner kepada responden digunakan untuk memperoleh data data pengetahuan tentang sastra dan minat membaca karya sastra.

Ada tiga instrumen penelitian ini: (1) tes kemampuan mengapresiasi karya sastra; (2) kuesioner (angket) pengetahuan tentang sastra; dan (3) angket (kuesioner) minat membaca karya sastra. Selanjutnya, analisis regresi dan korelasi secara sederhana maupun ganda digunakan untuk menganalisis data.

\section{HASIL DAN PEMBAHASAN}

\section{Data Y (Kemampuan}

Mengapresiasi Karya Sastra)

Data variabel ini: skor tertinggi 90 dan skor terendah 48 . Mean (rerata skor) 64,96; median (nilai tengah) adalah 64; dan modus (nilai yang banyak muncul) sebesar 60. Selanjutnya, simpangan baku (standar deviasi) dari data ini adalah 8,85 .

\section{Data Pengetahuan tentang Sastra} $\left(X_{1}\right)$

Data variabel pengetahuan tentang sastra memperoleh skor tertinggi 132 dan skor terendah 84 . Mean (rerata skor)-nya sebesar103; median (nilai tengah) adalah 102; dan modus (nilai yang banyak muncul) sebesar 84. Selanjutnya, simpangan baku (standar deviasi) dari data ini adalah 12,73 . 
Data $\mathrm{X}_{2}$ (Minat Membaca Karya Sastra)

Data variabel ini: skor tertinggi 139, terendah 80. Nilai Mean (rerata skor)-nya sebesar 101; median (nilai tengah) adalah 101; dan modus (nilai yang banyak muncul) sebesar 80. Selanjutnya, simpangan baku (standar deviasi) dari data

$$
\text { ini adalah } 13,71 \text {. }
$$

\section{Hasil Uji Normalitas Data}

Uji normalitas mengunakan dengan teknik lilliefors. (Sudjana, 2003,466-468) dapat dilihat pada tabel dibawah ini:

\begin{tabular}{lll}
\hline Nama Data & Lo & Lt \\
\hline KMKS $(Y)$ & 0,0849 & 0,0934 \\
\hline PS $\left(X_{1}\right)$ & 0,0912 & 0,0934 \\
\hline MMKS $\left(X_{2}\right)$ & 0,0925 & 0,0934 \\
\hline
\end{tabular}

Sesuai uraian tabel di atas, diperoleh hasil pengujian normalitas data kemampuan mengapresiasi karya sastra $(\mathrm{Y})$, pengetahua tentang sastra $\left(\mathrm{X}_{1}\right)$, dan minat membaca karya sastra $\left(\mathrm{X}_{2}\right)$ menghasilkan $\mathrm{L}_{0}<$ Lt. Pengujian nilai kritis L untuk Uji Lilliefors dengan nilai $n=90$ serta taraf nyata $\alpha=0,05$ terlihat bahwa $\mathrm{L}_{\mathrm{t}}$ lebih besar dari $\mathrm{L}_{\mathrm{o}}$. Artinya, dapat ditarik kesimpulan bahwa ketiga data pada varibel penelitian ini berasal dari populasi yang berdistribusi normal.

\section{Pemeriksaan Hipotesis}

\section{Hubungan antara Pengetahuan tentang Sastra dengan Kemampuan Mengapresiasi Karya Sastra}

Hipotesis pertama, terdapat hubungan positif antara pengetahuan

176 | Jurnal Kredo Vol. 2 No. 1 Oktober 2018 tentang sastra dengan kemampuan mengapresiasi karya sastra. Pada kesempatan ini akan diuji hipotesis nol $\left(\mathrm{H}_{0}\right)$. Artinya, "tidak ada hubungan positif antara pengetahuan tentang sastra dengan kemampuan mengapresiasi karya sastra" melawan hipotesis opsi $\left(\mathrm{H}_{1}\right)$ berbunyi, "ada hubungan positif antara pengetahuan tentang sastra dengan kemampuan mengapresiasi karya sastra".

Analisis regresi linear sederhana antara pengetahuan tentang sastra dengan kemampuan mengapresiasi karya sastra menghasilkan persamaan $\hat{Y}=48,65$ $+0,15 X_{1}$. Artinya koefisien arah regresi sederhana $\mathrm{Y}$ atas $\mathrm{X}_{1}$ sebesar 0,15 dan konstanta sebesar 48,65. Untuk memperoleh derajat keberartian persamaan regresi sederhana antara pengetahuan tentang sastra dengan kemampuan mengapresiasi karya sastra maka dilakukan uji $\mathrm{F}$ menggunakan pendekatan tabel anava. Hasil pengujian diperoleh nilai $\mathrm{F}_{0}$ sebesar 4,82. Nilai ini lebih besar dari $F_{\text {tabel: }}$ : 3,96 Artinya, persamaan regresi pengetahuan tentang sastra dengan kemampuan mengapresiasi karya sastra dikatakan signifikan (berarti). Hasil uji linearitas menghasilkan $\mathrm{F}_{0}$ sebesar 1,34 dan nilai $F_{\text {tabel }}$ sebesar 1,63. Nilai ini menunjukkan nilai hitung lebih besar dari nilai tabel. Dengan demikian, hubungan antara pengetahuan tentang sastra dengan kemampuan mengapresiasi karya sastra bersifat linear.

Analisis korelasi sederhana antara pengetahuan tentang sastra dengan kemampuan mengapresiasi karya sastra diperoleh koefisien korelasi $\left(\rho_{\mathrm{y} 1}\right)$ sebesar 0,22 . Sementara, pengujian keberartian korelasi menggunakan uji t. Hasilnya kekuatan hubungan antara 
pengetahuan tentang sastra dengan kemampuan mengapresiasi karya sastra 2,12 memperopleh nilai lebih besar dari $t_{\text {tabel }}$ sebesar 1,66. Dengan demikian, sesuai dengan pengujian tersebut, terdapat hubungan positif yang signifikan antara pengetahuan tentang sastra dengan kemampuan mengapresiasi karya sastra. Sehingga, hipotesis nol $\left(\mathrm{H}_{0}\right)$ "tidak ada hubungan antara pengetahuan tentang sastra dengan kemampuan mengapresiasi karya sastra" ditolak. Sebaliknya, hipotesis preferensi $\left(\mathrm{H}_{1}\right)$ "ada hubungan positif antara pengetahuan tentang sastra dengan kemampuan mengapresiasi karya sastra" diterima.

Koefisien determinan antara pengetahuan tentang sastra dengan kemampuan mengapresiasi karya sastra 4,84\% (didapat dari koefisien korelasi yang dikuadratkan $\mathrm{X}_{1}-\mathrm{Y}$, selanjuynta dikalikan 100\%). Artinya, variabel pengetahuan tentang sastra memberi kontribusi 4, 84\% kepada variabel kemampuan mengapresiasi karya sastra.

Hubungan antara Minat Membaca Karya Sastra dengan Kemampuan Mengapresiasi Karya Sastra

Hipotesis kedua yaitu terdapat hubungan positif antara minat membaca karya sastra dengan kemampuan mengapresiasi karya sastra. Pada kesempatan ini, pengujian hipotesis nol $\left(\mathrm{H}_{0}\right)$, berbunyi: "tidak ada hubungan positif antara minat membaca karya sastra dengan kemampuan mengapresiasi karya sastra melawan hipotesis alternatif $\left(\mathrm{H}_{1}\right)$, berbunyi "ada hubungan positif antara minat membaca karya sastra dengan kemampuan mengapresiasi karya sastra".
Analisis regresi linear sederhana antara minat membaca karya sastra dengan kemampuan mengapresiasi karya sastra memperoleh persamaan $=47,52+$ $0,17 \mathrm{X}_{2}$. Artinya koefisien arah regresi sebesar 0,17 dan konstanta 47,52. Selanjutnya dilakukan uji uji $\mathrm{F}$ menggunakan pendekatan tabel anava bertujuan mengetahui derajat keberartian persamaan regresi sederhana antara $\left(\mathrm{X}_{2}\right)$ dengan $(\mathrm{Y})$. Diperoleh hasil keberartian regresi $\mathrm{F}_{0}$ sebesar 6,81 sedangkan nilai $\mathrm{F}_{\text {tabel }}$ sebesar 3,96. Dengan demikian, persamaan regresi antara minat membaca karya sastra dengan kemampuan mengapresiasi karya sastra disebut signifikan (berarti) karena nilai pengujian atau $\left(\mathrm{F}_{0}\right)$ lebih besar dari nilai tabel $\left(\mathrm{F}_{\mathrm{t}}\right)$. Sementara, hasil uji linearitas $\mathrm{F}_{0}$ : 1,68 lebih kecil dari nilai $F_{\text {tabel }}$ sebesar 1,80. Hal ini menujukkan bahwa hubungan antara minat membaca karya sastra dengan kemampuan mengapresiasi karya sastra dikatakan linear.

$$
\text { Penghitungan korelasi }
$$
sederhana antara minat membaca karya sastra dan kemampuan mengapresiasi karya sastra diperoleh koefisien korelasi $\left(\rho_{\mathrm{y} 2}\right)$ sebesar 0,26.

Selanjutnya, dilakukan uji t untuk memperoleh keberartian koefisien korelasi. Dari hasil tersebut, terdapat kekuatan hubungan antara minat membaca karya sastra dengan kemampuan mengapresiasi karya sastra sebesar 2,53 dan $t_{\text {tabel }}$ sebesar 1,66. Koefisien ini membuktikan bahwa nilai $X_{2}>Y$. Kesimpulannya, terdapat hubungan positif yang signifikan antara minat membaca karya sastra dengan kemampuan mengapresiasi karya sastra. Berdasarkan pernyataan tersebut, hipotesis nol $\left(\mathrm{H}_{0}\right)$ menyatakan "tidak 
ada hubungan positif antara minat membaca karya sastra dengan kemampuan mengapresiasi karya sastra" ditolak. Selanjutya, hipotesis alternatif $\left(\mathrm{H}_{1}\right)$, "ada hubungan positif antara minat membaca karya sastra dengan kemampuan mengapresiasi karya sastra" diterima.

Koefisien determinan antara $\mathrm{X}_{2}$ dengan $\mathrm{Y}$ sebesar $6,76 \%$ (ddidapatkan dari harga koefisien $\mathrm{X}_{2}$ - $\mathrm{Y}$ yang dikuadratkan kemudian dikalikan 100\%). Artinya, variabel minat membaca karya sastra memberi kontribusi sebesar $6,76 \%$ kepada variabel kemampuan mengapresiasi karya sastra.

\section{Hubungan antara Pengetahuan tentang Sastra dan Minat Membaca Karya Sastra Secara Bersama-sama dengan Kemampuan Mengapresiasi Karya Sastra}

Hipotesis terakhir yaitu terdapat hubungan positif antara pengetahuan tentang sastra dan minat membaca karya sastra dengan kemampuan mengapresiasi karya sastra.secara secara bersama-sama. Diuji hipotesis nol $\left(\mathrm{H}_{0}\right)$, "tidak ada hubungan antara pengetahuan tentang sastra dan minat membaca karya secara bersama-sama dengan kemampuan mengapresiasi karya sastra", melawan hipotesis alternatif $\left(\mathrm{H}_{1}\right)$, "ada hubungan positif antara pengetahuan tentang sastra dan minat membaca karya sastra secara bersama-sama dengan kemampuan mengapresiasi karya sastra".

Analisis regresi linear ganda secara bersama-sama antara pengetahuan tentang sastra dan minat membaca karya sastra dengan kemampuan mengapresiasi karya sastra, memperoleh koefisien regresi $\mathrm{b}_{1}$ bernilai 0,$126 ; \mathrm{b}_{2}: 0,149$; dan konstanta $\quad b_{0}: \quad 36,90 . \quad$ Dengan demikian, bentuk hubungan antara $\mathrm{X}_{1}$ dan $\mathrm{X}_{2}$ terhadap $\mathrm{Y}$ menghasilkan persamaan regresi, yaitu $\widehat{Y}=36,90+$ $0,126 X_{1}+0,149 X_{2}$. Berikutnya dilakukan $F$ untuk mengetahui derajat keberartian persamaan regresi linear ganda antara pengetahuan tentang sastra dan minat membaca karya sastra secara bersama-sama dengan kemampuan mengapresiasi karya sastra.

Berdasarkan pengujian derajat keberartian memperoleh hasil pengujian $F_{0}$ sebesar 5,01, lebih besar dari $\mathrm{F}_{\text {tabel }}$ dengan $\mathrm{dk}$ pembilang 2 dan dk penyabut 87 pada $\alpha=0,05$ sebesar 3,11. Kondisi ini membuktikan hasil yang signifikan terhadap persamaan regresi linier antara pengetahuan tentang sastra dan minat membaca karya sastra secara bersama-sama dengan kemampuan megapresiasi karya sastra.

Selain itu, hasil analisis korelasi ganda memperoleh nilai korelasi $\quad\left(\mathrm{R}_{\mathrm{y} .12}\right)$ sebesar 0,32. Selanjutnya, untuk mengetahui keberartian koefisien korelasi ganda, dilakukan uji F. Hasilnya diperoleh nilai $F_{0}$ sebesar 5,01 lebih besar dari $\mathrm{F}_{\text {tabel }}$ dengan $\mathrm{dk}$ pembilang $2 \mathrm{dan} \mathrm{dk}$ penyebut 87 pada taraf nyata $\alpha=$ 0,05 sebesar 3,11. Dengan demikian, terdapat hubungan positif yang signifikan antara pengetahuan tentang sastra dan minat membaca karya sastra dengan kemampuan mengapresiasi karya sastra.

Koefisien determinan kedua variabel tersebut sebesar $10,24 \%$ (diperoleh dari harga koefisien korelasi ganda dikuadrakan selanjutnya dikalikan dengan $100 \%$ ). Hasilnya menunjukkan 10,24\% variansi kemampuan mengapresiasi karya sastra dapat dipengaruhi oleh 
pengetahuan tentang sastra dan minat membaca karya sastra secara bersama-sama.

\section{PEMBAHASAN}

Secara teoretis penelitian ini membahas tentang kemampuan mengapresiasi karya sastra dengan pengetahuan tentang sastra dan minat membaca karya sastra. Artinya, agar mahasiswa memiliki kemampuan mengapresiasi karya sastra yang dapat diandalkan, diperlukan faktor pendukung atau determinan antara lain faktor pengetahuan tentang sastra dan minat membaca karya sastra.

Pertama, hasil pengujian hubungan antara pengetahuan tentang sastra dengan kemampuan mengapresiasi karya sastra diterima. Hal ini ditunjukkan dengan hasil pengujian kekuatan hubungan antara pengetahuan tentang sastra dengan kemampuan mengapresiasi karya sastra bernilai 2,12 lebih besar dari $t_{\text {tabel }}$ sebesar 1,66. Selanjutnya kontribusi (sumbangan) variabel pengetahuan tentang sastra kepada variabel kemampuan mengapresiasi karya sastra sebesar 4,84\%. Dengan demikian kedua variabel tersebut memiliki hubungan positif, artinya makin baik pengetahuan tentang sastra mahasiswa, semakin baik kemampuan mengapresiasi karya sastranya.

Kedua, hasil penghitugan hubungan antara minat membaca karya sastra dan kemampuan mengapresiasi karya sastra diterima. Pernyataan ini diketahui hasil uji kekuatan hubungan antara minat membaca karya sastra dan kemampuan mengapresiasi karya sastra bernilai 2,53 yang lebih besar dari $t_{\text {tabel }}$ sebesar 1,66. Selanjutnya kontribusi (sumbangan) variabel minat membaca karya sastra kepada variabel kemampuan mengapresiasi karya sastra sebesar $6,76 \%$. Dengan demikian variabel-variabel variabel tersebut saling berkaitan secara positif, artinya semakin tinggi minat membaca karya sastra mahasiswa, semakin baik kemampuan mengapresiasi karya sastranya.

Ketiga, hubungan antara kedua variabel bebas secara dengan kemampuan mengapresiasi karya sastra, diterima. Hal ini ditunjukkan dari dengan hasil analisis kekuatan hubungan diperoleh nilai sebesar 5,01 lebih besar dari $t_{\text {tabel }}$ sebesar 3,11 . Kontribusi (sumbangan) kedua variabel tersebut kepada variabel kemampuan mengapresiasi karya sastra sebesar 10,24\%.

\section{SIMPULAN}

Berdasarkan penghitungan dan pengujian hipotesis, semuanya memperoleh hasil yang berterima. Temuan ini berarti, mahasiswa Universitas Hamzanwadi (luar jurusan PBS) tahun akademik 2017/2018 memiliki pengetahuan tentang sastra dan minat membaca karya sastra yang memiliki hubungan positif secara signifikan dengan kemampuan mengapresiasi karya sastra, baik sendiri-sendiri maupun secara bersama-sama. 


\section{DAFTAR PUSTAKA}

Abdurrahman, Mulyono. 2003. Pendidikan Bagi Anak Berkesulitan Belajar. Jakarta: Rineka Cipta.

Aminuddin. 1995. Stilistika: Pengantar Memahami Bahasa dalam Karya Sastra. Semarang: IKIP Semarang Press.

Arikunto, Suharsimi. 2006. Prosedur Penelitian Suatu Pendekatan Praktik. Jakarta: Rineka Cipta.

Budiono. 2003. Metodologi Penelitian Pendidikan. Surakarta: UNS Press.

Chaplin, James P. 2011. Kamus Psikologi (Terj. Kartini Kartono). Jakarta: Rajawali Press.

Djaali. 2012. Psikologi Pendidikan. Jakarta: Bumi Aksara.

Djamarah, Syaiful Bahri. 2011. Psikologi Belajar. Jakarta: Rineka Cipta.

Notoatmojo, S. 2005. Pendidikan dan Prilaku Kesehatan. Jakarta: Rineka Cipta.

Salam, Burhanuddin. 2003. Sejarah Filsafat Ilmu \& Teknologi. Jakarta; Rineka Cipta.

Sayuti, Suminto A. 2000. Berkenalan dengan Prosa Fiksi. Yogyakarta: Gama Media.

Sudjana. 2003. Teknik Analisis Regresi dan Korelasi. Bandung: Tarsito.

Suwarto dan Slamet St.Y. 2007. Dasar-Dasar Metode Penelitian Kuantitatif. Surakarta: PPs Universitas Sebelas Maret.

Syah, Muhibbin. 2010. Psikologi Pendidikan dengan Pendekatan Baru. Bandung: Remaja Rosdakarya.

Tarigan, Henry Guntur. 2008. Membaca Sebagai Suatu Keterampilan Berbahasa. Bandung: Angkasa.

Waluyo, Herman. J. 2011. Pengkajian dan Apresiasi Prosa Fiksi. Surakarta: UNS Press.

Wellek, Rene dan Austin Warren. 1989. Teori Kesusastraan (Terj. Melani Budianta). Jakarta: Grame.

180 | Jurnal Kredo

Vol. 2 No. 1 Oktober 2018 